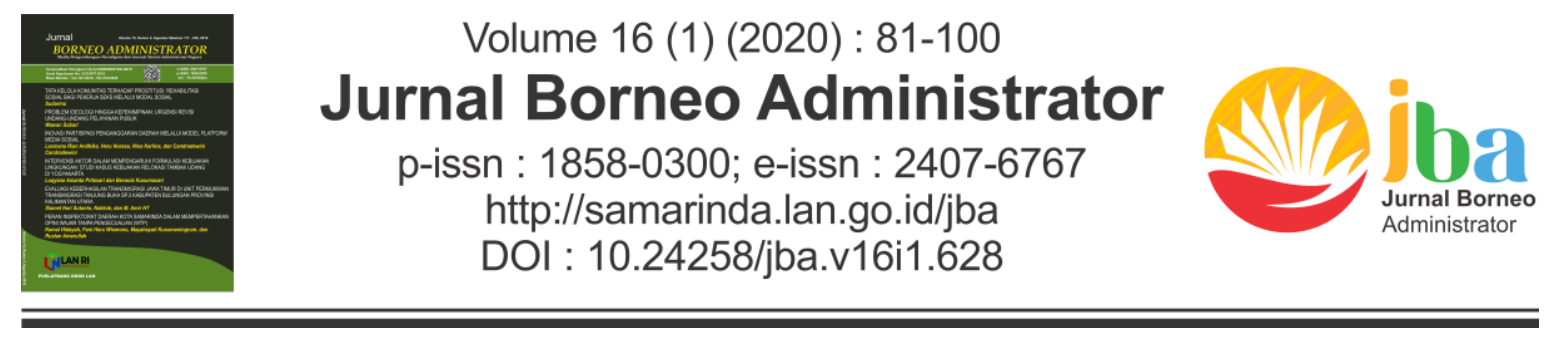

\title{
ANALISIS SPASIAL SEKTOR PARIWISATA DI PROVINSI KALIMANTAN SELATAN
}

\section{SPATIAL ANALYSIS OF TOURISM SECTOR IN KALIMANTAN SELATAN PROVINCE}

\author{
Kisfendie Regga Rahmad Igarta a dan Fitri Handayani ${ }^{b}$ \\ a Badan Pusat Statistik Kabupaten Barito Kuala \\ Jl. Jenderal Sudirman No. 72 Marabahan, Barito Kuala \\ ${ }^{b}$ Badan Pusat Statistik Provinsi Kalimantan Selatan \\ Jl. Soekarno Hatta/Trikora No. 7 Banjarbaru \\ Email: kisfendie@bps.go.id; fitri.fhandayani@gmail.com
}

Naskah diterima: 20 Desember 2019; revisi terakhir: 12 Februari 2020; disetujui 25 Maret 2020

How to Cite: Igarta, Kisfendie RR., dan Handayani, Fitri. (2020). Analisis Spasial Sektor Pariwisata di Provinsi Kalimantan Selatan. Jurnal Borneo Administrator, 16 (1), 81-100. https://doi.org/10.24258/jba.v16i1.628

\begin{abstract}
The Indonesian government is focusing on improving the tourism sector, hoping that this sector could become a stepping stone to put Indonesia as a developed country in 2045. Local governments who draw interest for the benefits earned by tourism sector also supported this expectation. Regarding policy design, it would be important if policy makers know the mapping and potential distribution of the sector. Therefore, the purpose of this paper is to identify spatial autocorrelation in the tourism sector in South Kalimantan Province. The analytical method used was a Moran Index. Based on the results of the analysis, each field of business in the tourism sector had a Moran Index value of 0.168 for trade, 0.017 for transportation and storage, 0.114 for the accommodation and food service activities, and 0.003 for other service activities. The Moran Index showed a positive tourism sector autocorrelation between districts/cities. From the results of the spatial autocorrelation analysis, the tourism sector which was a priority for spreading its impact on other regions was on the trade business field.
\end{abstract}

Keywords: Tourism, Spatial Autocorrelation, Moran Index

\begin{abstract}
Abstrak
Pemerintah Indonesia sedang berfokus pada peningkatan sektor pariwisata dengan harapan sektor ini dapat menjadi tumpuan ekonomi Indonesia yang akhirnya menempatkan Indonesia sebagai negara maju pada 2045. Harapan ini pun didukung oleh pemerintah daerah yang juga memiliki ketertarikan terhadap keuntungan yang dihasilkan dengan adanya peningkatan pada sektor pariwisata. Berkaitan dengan rancangan kebijakan, akan menjadi penting jika pembuat kebijakan mengetahui
\end{abstract}


pemetaan dan sebaran potensi sektor tersebut sehingga tujuan dari penelitian ini adalah untuk mengidentifikasi adanya autokorelasi spasial pada sektor pariwisata di Provinsi Kalimantan Selatan. Metode analisis yang digunakan adalah Indeks Moran dengan data sekunder berupa Produk Domestik Regional Bruto (PDRB). Berdasarkan hasil analisis tersebut, tiap-tiap lapangan usaha pada sektor pariwisata memiliki nilai Indeks Moran sebesar 0,168 untuk perdagangan, 0,017 untuk transportasi dan pergudangan, 0,114 untuk penyediaan akomodasi dan makan minum, dan 0,003 untuk jasa lainnya. Nilai Indeks Moran tersebut menunjukkan adanya autokorelasi sektor pariwisata yang positif antarkabupaten/kota satu dengan yang lainnya. Dari hasil analisis autokorelasi spasial, sektor pariwisata yang menjadi prioritas untuk menyebarkan dampaknya pada wilayah lain adalah lapangan usaha perdagangan.

Kata Kunci: Pariwisata, Autokorelasi Spasial, Indeks Moran

\section{A. PENDAHULUAN}

Saat ini sektor pariwisata menjadi sektor yang dianggap penting untuk mendorong pertumbuhan ekonomi yang berkelanjutan. Bahkan pemerintahan Indonesia sedang berfokus pada peningkatan sektor pariwisata dengan harapan sektor ini dapat menjadi tumpuan ekonomi Indonesia yang akhirnya menempatkan Indonesia sebagai negara maju pada 2045. Harapan besar ini tertuang pula dalam 7 Agenda Pembangunan RPJMN IV tahun 2020-2024, khususnya pada Agenda "Memperkuat Ketahanan Ekonomi untuk Pertumbuhan yang Berkualitas" (Kementerian PPN/Bappenas, 2019). Dalam agenda tersebut disebutkan bahwa pembangunan ekonomi akan dipacu untuk tumbuh lebih tinggi, inklusif, dan berdaya saing salah satunya melalui akselerasi peningkatan nilai tambah pariwisata.

Berbagai keuntungan dapat diperoleh dari peningkatan sektor pariwisata. Menurut The World Bank Group (2017), sektor pariwisata berkaitan erat dengan pertumbuhan ekonomi berkelanjutan; inklusivitas sosial, ketenagakerjaan, dan pengurangan kemiskinan; efisiensi sumber daya, perlindungan lingkungan, dan iklim; nilai-nilai budaya, keanekaragaman, dan warisan; serta kedamaian dan keamanan. Keuntungan lain yang didapat dari pengembangan sektor pariwisata adalah meningkatkan pertumbuhan bisnis, menciptakan lapangan kerja, dan mengurangi kemiskinan (Wang and Pfister, 2008 dalam Adeola, Ogechi \& Evans, Olaniyi \& Hilson, 2018:147-160). Selain itu berdasarkan Renstra Kementerian Pariwisata RI 2015-2019, kepariwisataan yang memiliki karakter multisektor dan lintas regional, secara konkret dan efektif mampu mendorong pembangunan infrastruktur dan fasilitas kepariwisataan yang pada gilirannya menggerakkan arus investasi dan pengembangan wilayah.

Dengan mengetahui berbagai keuntungan yang diciptakan oleh sektor pariwisata, hal ini membuat sektor tersebut menjadi sektor yang diminati pemerintah daerah sebagai sektor unggulan. Untuk daerah yang ekonominya didominasi oleh pengeksploitasian sumber daya alam, sektor pariwisata menjadi sektor yang dianggap dapat membantu percepatan pertumbuhan ekonomi ketika sumber daya alam yang dieksploitasi tersebut semakin berkurang.

Provinsi Kalimantan Selatan sebagai daerah yang ekonominya berbasis pertambangan batubara, perlahan mulai berfokus pada pengembangan sektor pariwisata. Sektor ini pun menjadi salah satu program prioritas di tahun 2016-2021 dengan tujuan menjadikan Kalimantan Selatan sebagai salah satu destinasi nasional. Berbagai event dan infrastruktur berkaitan dengan sektor pariwisata sudah mulai diciptakan oleh pemerintah daerah. Salah satu yang menjadi fokus adalah Visit Kalsel 2020 yang diharapkan menjadi pintu gerbang 
tercapainya tujuan pemerintah untuk menjadikan sektor pariwisata sebagai salah satu sektor yang dapat menopang perekonomian daerah.

Potensi Kalimantan Selatan dalam hal kepariwisataan cukup besar, baik dalam hal wisata alam maupun wisata budaya. Potensi sektor pariwisata ini tersebar di wilayah kabupaten/kota Provinsi Kalimantan Selatan. Satu hal yang penting adalah bagaimana mengetahui pemetaan dan sebaran potensi tersebut di seluruh wilayah Kalimantan Selatan. Dengan melihat sebaran potensi beserta analisis spasialnya, kebijakan dan program dapat dijalankan dengan efektif dan efisien.

Berdasarkan uraian di atas, maka kajian ini bertujuan untuk mengidentifikasi adanya autokorelasi spasial pada sektor pariwisata di Provinsi Kalimantan Selatan. Jika ternyata mempunyai korelasi, kebijakan dapat diarahkan secara terintegrasi dalam beberapa wilayah berbatasan. Dengan berpedoman pada hasil ini akan didapatkan gambaran bagaimana rancangan dalam mengambil kebijakan terhadap pengembangan sektor pariwisata berdasarkan kedekatan spasial.

\section{B. METODE PENELITIAN}

Penelitian ini menggunakan data sekunder dengan jenis data cross section pada tahun 2018. Adapun data utama yang digunakan dalam penelitian ini meliputi nilai tambah sektor pariwisata yang diukur dari Produk Domestik Regional Bruto (PDRB). Sektor pariwisata dalam penelitian ini dibatasi pada lapangan usaha perdagangan, transportasi dan pergudangan, penyediaan akomodasi dan makan minum, serta jasa lainnya. Hal ini sesuai dengan penelitian Atan \& Arslanturk (2012:952-956) dan Williams (2016:1-16) yang menerapkan beberapa sektor tersebut sebagai sektor pariwisata. Data PDRB diperoleh dari publikasi resmi yang dilakukan oleh BPS Provinsi Kalimantan Selatan. Selain itu, diperlukan juga peta administrasi kabupaten/kota untuk menentukan letak dan batas administrasi kabupaten yang digunakan sebagai matriks pembobot spasial.

Penelitian ini menggunakan analisis deskriptif dan inferensia. Metode deskriptif adalah metode yang berkaitan dengan pengumpulan dan penyajian suatu gugus data sehingga memberikan informasi yang berguna. Metode ini digunakan untuk memberikan gambaran kondisi sektor pariwisata kabupaten/kota se-Kalimantan Selatan.

Model analisis inferensia yang digunakan adalah analisis autokorelasi spasial. Hal itu sesuai dengan tujuan di awal bahwa tujuan kajian ini adalah untuk mengidentifikasi apakah terjadi autokorelasi spasial sektor pariwisata kabupaten/kota di Kalimantan Selatan. Data sekunder tersebut kemudian diolah dan dianalisis dengan menggunakan aplikasi GeoDa. Selain itu, digunakan pula aplikasi Sistem Informasi Geografis (GIS) untuk mendapatkan peta sebaran sektor pariwisata di Provinsi Kalimantan Selatan.

\section{Analisis Data Spasial}

Data spasial adalah data yang berkaitan dengan lokasi berdasarkan geografi yang terdiri dari lintang-bujur dan wilayah. Analisis data spasial tidak dapat dilakukan secara global, artinya setiap lokasi mempunyai karakteristik sendiri. Sebagian besar pendekatan analisisnya merupakan eksplorasi data yang disajikan dalam bentuk peta tematik. Peta tematik juga disebut sebagai peta statistik atau peta tujuan khusus, menghasilkan gambaran penggunaan ruangan pada tempat tertentu sesuai dengan tema yang diinginkan. Berbeda dengan peta rujukan yang memperlihatkan pengkhususan geografi (hutan, jalan, perbatasan administratif), peta-peta tematik lebih menekankan variasi penggunaan ruangan daripada sebuah jumlah atau lebih dari distribusi geografis. Distribusi geografis bisa berupa fenomena fisikal, seperti iklim atau ciri-ciri khas manusia seperti kepadatan penduduk atau 
permasalahan kesehatan (Pfeiffer (2008) dalam Rahmawati, Safitri, \& Fairuzdhiya (2015:23-30).

Analisis spasial terdiri atas tiga kelompok, yaitu visualisasi, eksplorasi, dan pemodelan. Visualisasi adalah menginformasikan hasil analisis spasial. Eksplorasi adalah mengolah data spasial dengan metode statistika. Sedangkan pemodelan adalah menunjukkan adanya konsep hubungan sebab akibat dengan menggunakan metode dari sumber data spasial dan data nonspasial untuk memprediksi adanya pola spasial. Lokasi pada data spasial harus diukur agar dapat mengetahui adanya efek spasial yang terjadi. Menurut Kosfeld (2006) dalam Wuryandari, Hoyyi, \& Kusumawardani (2014:1-10), informasi lokasi dapat diketahui dari dua sumber, sebagai berikut: (1) Hubungan ketetanggaan (neighborhood) mencerminkan lokasi relatif dari satu unit spasial atau lokasi ke lokasi yang lain dalam ruang tertentu. Hubungan ketetanggaan dari unit-unit spasial biasanya dibentuk berdasarkan peta. Ketetanggaan dari unit-unit spasial ini diharapkan dapat mencerminkan derajat ketergantungan spasial yang tinggi jika dibandingkan dengan unit spasial yang letaknya terpisah jauh. (2) Jarak (distance) Lokasi yang terletak dalam suatu ruang tertentu dengan adanya garis lintang dan garis bujur menjadi sebuah sumber informasi. Informasi inilah yang digunakan untuk menghitung jarak antartitik yang terdapat dalam ruang. Diharapkan kekuatan ketergantungan spasial akan menurun sesuai dengan jarak yang ada. Hal yang sangat penting dalam analisis spasial adalah adanya pembobot atau sering disebut sebagai matriks pembobot spasial. Matriks pembobot spasial digunakan untuk menentukan bobot antarlokasi yang diamati berdasarkan hubungan ketetanggaan antarlokasi.

Menurut Kosfeld, pada grid umum ketetanggaan dapat didefinisikan dalam beberapa cara, yaitu: (1) Rook contiguity Daerah pengamatannya ditentukan berdasarkan sisi-sisi yang saling bersinggungan dan sudut tidak diperhitungkan. Ilustrasi rook contiguity dilihat pada Gambar 1, dimana unit B1, B2, B3, dan B4 merupakan tetangga dari unit A.

\begin{tabular}{|l|l|l|l|l|}
\hline & & & & \\
\hline & & Unit B2 & & \\
\hline & Unit B1 & Unit A & Unit B3 & \\
\hline & & Unit B4 & & \\
\hline & & & & \\
\hline
\end{tabular}

Gambar 1.

Rook Contiguity (Sumber: Kosfeld, 2006 dalam Wuryandari et al., 2014:1-10)

(2) Bishop contiguity Daerah pengamatannya ditentukan berdasarkan sudut-sudut yang saling bersinggungan dan sisi tidak diperhitungkan. Ilustrasi untuk bishop contiguity dilihat pada Gambar 2, menunjukkan bahwa unit C1, C2, C3, dan C4 merupakan tetangga dari unit A. 


\begin{tabular}{|l|l|l|l|l|}
\hline & & & & \\
\hline & Unit C1 & & Unit C2 & \\
\hline & & Unit A & & \\
\hline & Unit C4 & & Unit C3 & \\
\hline & & & & \\
\hline
\end{tabular}

Gambar 2.

Bishop Contiguity (Sumber: Kosfeld, 2006 dalam Wuryandari et al., 2014:1-10)

(3) Queen contiguity Daerah pengamatannya ditentukan berdasarkan sisi-sisi yang saling bersinggungan dan sudut juga diperhitungkan. Ilustrasi untuk queen contiguity dapat dilihat pada Gambar 3, menunjukkan bahwa unit B1, B2, B3, dan B4 serta C1, C2, C3, dan C4 merupakan tetangga dari unit A.

\begin{tabular}{|l|c|c|c|l|}
\hline & & & & \\
\hline & Unit C1 & Unit B2 & Unit C2 & \\
\hline & Unit B1 & Unit A & Unit B3 & \\
\hline & Unit C4 & Unit B4 & Unit C3 & \\
\hline & & & & \\
\hline
\end{tabular}

Gambar 3.

Queen Contiguity (Sumber: Kosfeld, 2006 dalam Wuryandari et al., 2014:1-10)

\section{Autokorelasi Spasial (Spatial Autocorrelation)}

Autokorelasi mengukur korelasi suatu variabel dengan dirinya sendiri, ketika pengamatan dipertimbangkan dengan jeda waktu (autokorelasi temporal) atau dalam ruang (autokorelasi spasial). Autokorelasi spasial didefinisikan sebagai korelasi positif atau negatif dari suatu variabel dengan dirinya sendiri karena lokasi spasial dari pengamatan. Autokorelasi spasial ini pertama-tama dapat merupakan hasil dari proses yang tidak dapat diobservasi atau sulit diukur yang menggabungkan berbagai lokasi. Kedua, dalam konteks spesifikasi model ekonometrik, mengukur autokorelasi spasial dapat dianggap sebagai alat untuk mendiagnosis dan mendeteksi spesifikasi yang salah (Tiefelsdorf, 1998 dalam Salima dan Marie-Pierre, 2018:51-68).

Selain itu, autokorelasi spasial menggambarkan kemiripan rata-rata dari nilai-nilai suatu seri dalam kaitannya dengan nilai-nilai yang terletak di lingkungan tersebut (Dubé, 2014:60). Dengan kata lain, nilai variabel, di lokasi tertentu, mungkin terkait dengan nilai yang diambil oleh variabel yang sama ini di area terdekat. Fenomena yang terletak di area yang sama mempengaruhi fenomena lain yang berada di dekatnya, yang pada gilirannya berinteraksi dengan fenomena lain yang dekat secara spasial. Semua saling ketergantungan ini mengungkapkan tingkat organisasi tertentu dari nilai-nilai variabel dalam ruang.

Dari sudut pandang statistik, banyak analisis seperti analisis korelasi, regresi linier, dll didasarkan pada hipotesis independensi variabel. Ketika suatu variabel secara spasial memiliki autokorelasi, hipotesis independensi tidak lagi dianggap, sehingga meragukan validitas hipotesis berdasarkan analisis yang dilakukan. Kedua, analisis autokorelasi spasial memungkinkan analisis kuantitatif pada struktur spasial dari fenomena yang diteliti. 
Harus ditekankan bahwa struktur spasial dan autokorelasi spasial tidak dapat eksis secara independen satu sama lain (Tiefelsdorf, 1998 dalam Salima dan Marie-Pierre, 2018:51-68). Istilah struktur spasial mengacu pada semua hubungan yang dengannya fenomena autokorelasi akan menyebar. Selanjutnya, tanpa kehadiran proses autokorelasi yang signifikan, struktur spasial tidak dapat diamati secara empiris. Distribusi spasial yang diamati kemudian dianggap sebagai manifestasi dari proses spasial yang mendasarinya.

Menurut Gujarati (1991), autokorelasi spasial dapat diuji, baik secara global maupun lokal wilayah tersebut (Nisa, 2017:206-226). Baik secara global maupun lokal, pengujian autokorelasi melibatkan suatu bobot yang disebut Matriks Pembobot Spasial (spatial weight matrix) yang menggambarkan kedekatan hubungan antar lokasi. Matriks pembobot spasial disebut juga sebagai matriks yang menggambarkan kekuatan interaksi antarlokasi. Gambar 4 menunjukkan kedekatan (contiguity) posisi atau letak suatu lokasi terhadap lokasi lainnya.

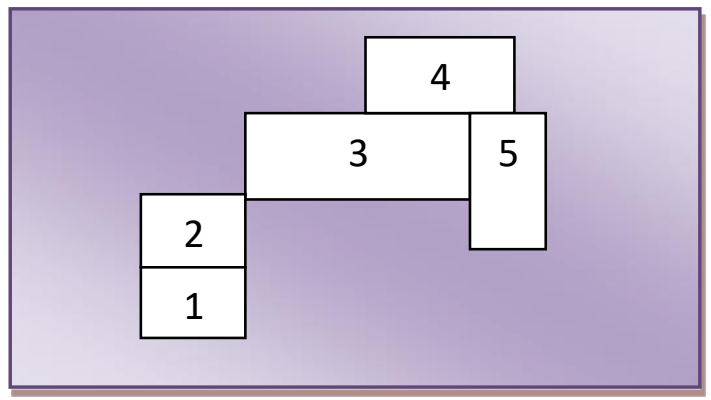

Gambar 4.

Ilustrasi Kedekatan Lokasi (Contiguity)

(Sumber: Gujarati, 1991 dalam Nisa (2017:206-226)

Menurut Anselin (1988:39-80), matriks pembobot dapat dibedakan menjadi: (1) Rook contiguity, daerah pengamatannya ditentukan berdasarkan sisi-sisi yang saling bersinggungan dan sudut tidak diperhitungkan. Bishop contiguity, daerah pengamatannya ditentukan berdasarkan sudut-sudut yang saling bersinggungan dan sisi tidak diperhitungkan. (2) Queen contiguity, daerah pengamatannya ditentukan berdasarkan sisisisi yang saling bersinggungan dan sudut juga diperhitungkan.

\section{Indeks Moran}

Pengujian Moran I digunakan untuk autokorelasi spasial global pada data yang kontinu. Metode ini dapat digunakan untuk mendeteksi permulaan dari keacakan spasial. Metode indeks Moran dapat dilakukan dengan cara (Banerjee, 2004 dalam Lutfi, Aidid, \& Sudarmin, 2019:1-8).

$$
I=\frac{n \sum_{i=1}^{n} \sum_{j=1}^{n} w_{i j}\left(x_{i}-\bar{x}\right)}{\sum_{i \neq j}^{n} w_{i j} \sum_{i=1}^{n} w_{i j}\left(x_{i}-\bar{x}\right)^{2}}
$$

Dimana: I: Indeks Moran; $\mathrm{n}$ : banyaknya lokasi kejadian; $x_{i}$ : nilai pada lokasi $i ; x_{i}$ : nilai pada lokasi $j ; \bar{x}$ : rata-rata dari keseluruhan objek; $w_{i j}$ : elemen pada pembobot terstandarisasi antara daerah $i$ dan $j$.

Nilai dari indeks ini berkisar antara -1 sampai 1 . Nilai $-1 \leq I<0$ menunjukkan adanya autokorelasi spasial negatif, sedangkan nilai $0<I \leq 1$ menunjukkan adanya autokorelasi spasial positif dan 0 menyiratkan keacakan spasial yang sempurna (Tu dan Xia, 2008 dalam Fu, Jiang, Zhou, dan Zhou, 2014). Keistimewaan dari statistik uji Moran adalah memerlukan 
estimasi di bawah hipotesis nol dan hipotesis alternatif. Ini sama dengan uji Wald yang samasama memerlukan hipotesis nol dan hipotesis alternatif.

\section{KERANGKA TEORI}

\section{Pariwisata}

Menurut Zhongmei (2012:145-149), dibandingkan dengan industri secara umum, pariwisata memiliki fungsi khusus yang pengembangannya menciptakan beragam manfaat komprehensif lokal, seperti sosial, ekonomi, dan lingkungan. (1) Dampak multiplier dari ekonomi pariwisata karena sebagai industri yang komprehensif, pariwisata memiliki hubungan yang erat dengan industri lainnya. (2) Sebagai industri yang berorientasi pada layanan dan padat karya, pariwisata menyediakan ambang batas untuk mempekerjakan yang lebih rendah, menunjukkan kapasitas yang kuat untuk menyerap tenaga kerja. (3) Sebagai industri hijau, pariwisata menekankan pada satu jenis pengembangan tipe perlindungan. (4) Memajukan citra kota karena pengembangan pariwisata perkotaan dapat menciptakan tema hijau yang indah dengan lingkungan yang menyenangkan.

Pariwisata adalah kegiatan masyarakat dengan konsekuensi sosial, lingkungan, dan ekonomi (Frechtling, 2008:1-20). Intinya adalah pergerakan individu untuk meninggalkan suatu tempat sehari-harinya yang normal untuk jangka waktu yang singkat dan kemudian kembali ke rumah. Selama kegiatan tersebut, pengunjung tersebut mengkonsumsi barang dan jasa dari vendor yang membutuhkan aliran dana dari pengunjung ke organisasi vendor. Pengeluaran tersebut oleh dan atas nama pengunjung menghasilkan konsekuensi ekonomi di tempat-tempat yang dikunjungi, lingkungan pengunjung yang biasa, dan di tempat lain.

Pariwisata adalah fenomena sosial, budaya, dan ekonomi berkaitan dengan perpindahan orang ke tempat-tempat di luar tempat tinggal mereka yang biasa dan biasanya kesenangan yang menjadi motivasi (United Nations, 2010:1-277). Pariwisata berdampak pada ekonomi, lingkungan alam dan buatan, serta penduduk lokal di tempat-tempat yang dikunjungi dan para pengunjung itu sendiri.

Aktivitas pariwisata tidak dapat dipisahkan dari lingkungan alam dan budaya di sekitarnya (Aleksandar, Marija, \& G.R, 2017:271-284). Lingkungan dan budaya adalah titik fokus dari perkembangan pariwisata. Ada hubungan timbal balik antara pariwisata dan lingkungan. Sebagai contoh, fasilitas pariwisata yang padat mendorong degradasi lingkungan yang pada akhirnya akan mengarah pada penurunan daya tarik pariwisata. Keberlanjutan dari elemen lingkungan dan budaya penting untuk keberlangsungan aktivitas pariwisata di wilayah tersebut.

\section{Penelitian Terkait}

Beberapa penelitian yang berkaitan dengan kepariwisataan dan analisis spasial adalah sebagai berikut. Penelitian yang berjudul Tourism and Regional Development: A Spatial Econometric Model for Portugal at Municipal Level oleh Stankov (2017:106-114) bertujuan untuk mengetahui tren pengelompokan spasial menggunakan tingkat kedatangan wisatawan antara tahun 2001 dan 2013. Untuk mencapai tujuan penelitian, digunakan statistik Global Moran's I and Anselin's Local Moran's I. Hasil autokorelasi global menunjukkan adanya pengelompokan spasial yang rendah dan menurun untuk kedatangan wisatawan domestik dan pengelompokan spasial yang relatif stabil untuk wisatawan internasional.

Penelitian yang berjudul A Spatial Analysis of Tourism Infrastructure in Romania: Spotlight on Accommodation and Food Service Companies oleh Constantin (2018:1-16) bertujuan untuk mengetahui pola utama dari distribusi spasial perusahaan akomodasi dan 
jasa makanan di Rumania serta mengetahui wilayah geografis untuk pengembangan pariwisata. Hasil menunjukkan distribusi teritorial infrastruktur pariwisata yang tidak merata dibandingkan dengan lokasi objek wisata, perbedaan yang signifikan antara distribusi geografis perusahaan akomodasi dan jasa makanan dan menyarankan kebijakan yang berbeda untuk mendukung infrastruktur pariwisata.

Penelitian yang berjudul Tourism and Economic Growth: Spatial Perspective oleh Budirahmayani (2019:7-24) bertujuan untuk mengetahui apakah penyebaran pertumbuhan pariwisata terjadi atau tidak dan untuk menganalisis dampak sektor pariwisata terhadap produk domestik regional bruto (PDRB) di 33 provinsi di Indonesia dibandingkan dengan provinsi tetangga mereka. Hasilnya menunjukkan penyebaran (spillover) spasial positif pariwisata di antara 33 provinsi. Selain itu, akomodasi, produktivitas tenaga kerja pariwisata, dan pendidikan memiliki efek signifikan positif dan meningkatkan jumlah wisatawan di suatu provinsi.

Penelitian yang berjudul Spatial trends in tourism within South Africa: The expected and the surprising oleh McKelly et al. (2017:219) bertujuan untuk memberikan indikasi nilai analisis komparatif, seperti tren spasial dan dampak dari sektor pariwisata di ekonomi lokal di Afrika Selatan. Hasil penelitian ini menegaskan peran penting dari wilayah metropolitan, kota-kota sekunder, pantai, dan tujuan wisata tipikal dalam ekonomi ruang pariwisata. Studi ini juga menyoroti pentingnya beberapa tempat/ekonomi lokal yang secara tradisional tidak terkait dengan pariwisata, dan menggambarkan pentingnya pengeluaran pariwisata di ekonomi lokal dari berbagai kota yang mungkin tidak menjadi bagian dari tujuan wisata top di Afrika Selatan.

Penelitian yang berjudul A spatial analysis on the determinants of tourism performance in Japanese Prefecture oleh Romão \& Saito (2017:243-264) menunjukkan hasil bahwa adanya efek spasial yang mencerminkan pentingnya pariwisata daerah pusat Jepang. Selain itu, untuk mengamati bahwa daerah yang pariwisatanya memainkan peran yang lebih menonjol dalam hal kepentingannya dalam pekerjaan regional tidak menyajikan kinerja yang relatif tinggi dalam hal dampak dan manfaat ekonomi. Hasilnya menunjukkan bahwa struktur ekonomi regional yang lebih seimbang dan tingkat pendidikan yang lebih tinggi dari tenaga kerja berkontribusi untuk peningkatan nilai tambah pariwisata.

Penelitian yang berjudul Spatial Autocorrelation Method for Local Analysis of The EU oleh Melecky (2015:1102-1109) bertujuan untuk mengidentifikasi variabel-variabel yang relevan dalam wilayah dan waktu Uni Eropa, yang berkontribusi terhadap deteksi kesenjangan teritorial, dan konsekuensinya dalam kendala struktural wilayah yang dianalisis. Metode yang digunakan adalah Indeks Moran dan Local Indicators of Spatial Association. Hasil statistik autokorelasi spasial mendeteksi keberadaan saling ketergantungan antara nilainilai data di lokasi tetangga.

Penelitian yang berjudul Economic Impact from Development of the Coastal Town in Quensland on Tourism and Regional Economy oleh Williams (2016:1-16) mendiskusikan bagaimana cara untuk menciptakan kesempatan industri pariwisata untuk terintegrasi dengan lebih baik terhadap ekonomi regional. Alat analisis yang digunakan adalah analisis input output. Pada penelitian ini sektor yang dipertimbangkan sebagai sektor yang berkaitan dengan pariwisata adalah perdagangan eceran; jasa akomodasi dan makan minum; transportasi, pos, dan pergudangan; jasa persewaan dan real estate; jasa administratif dan pendukung; jasa kesenian dan rekreasi.

Penelitian yang berjudul Tourism and Economic Growth Nexus: an input output analysis in Turkey oleh Atan \& Arslanturk (2012:952-956) membahas tentang hubungan antara pariwisata dan pertumbuhan ekonomi dengan menggunakan analisis input output 
mencakup dampak keterkaitan ke depan dan ke belakang. Variabel yang digunakan untuk pertumbuhan ekonomi adalah pendapatan dan output produksi. Sedangkan, pariwisata diklasifikasi sebagai hotel dan restoran dan aktivitas penunjang transportasi; aktivitas sektor agen travel; aktivitas rekreasi, budaya, dan olahraga.

Penelitian yang berjudul Pola Keterkaitan Spasial Berdasarkan Produksi Pajale (Padi Jagung Kedelai) di Kabupaten Grobogan Tahun 2015 oleh Rukini (2017:223-231) bertujuan untuk mengetahui pola penyebaran produksi pajale dengan pendekatan spasial. Metode yang digunakan untuk memperoleh autokorelasi spasial adalah Indeks Moran. Hasil analisisnya menunjukkan adanya autokorelasi spasial positif tetapi korelasi kecil dan indeks ini memiliki pola spasial yang menggerombol (clustered). Artinya produksi pajale di wilayah kecamatan yang saling berdekatan di Kabupaten Grobogan saling memberi pengaruh antar satu dengan yang lain.

\section{HASIL DAN PEMBAHASAN}

\section{Autokorelasi Letak Kabupaten di Kalimantan Selatan}

Secara geografis Provinsi Kalimantan Selatan terletak di bagian selatan Pulau Kalimantan dengan batas-batas: sebelah barat dengan Provinsi Kalimantan Tengah, sebelah timur dengan Selat Makasar, sebelah selatan dengan Laut Jawa dan sebelah utara dengan Provinsi Kalimantan Timur (Badan Pusat Statistik Provinsi Kalimantan Selatan, 2019:3). Luas wilayahnya adalah sekitar 37.530,52 $\mathrm{km}^{2}$ atau 6,98 persen dari luas Pulau Kalimantan dan 1,96 persen dari luas wilayah Indonesia. Terdiri atas 13 kabupaten/kota, yaitu Tanah Laut, Kotabaru, Banjar, Barito Kuala, Tapin, Hulu Sungai Selatan, Hulu Sungai Tengah, Hulu Sungai Utara, Tabalong, Tanah Bumbu, Balangan, Banjarmasin, dan Banjarbaru.

Untuk melakukan penghitungan autokorelasi spasial, diperlukan penimbang sebagai bobot hitungnya. Metode yang digunakan untuk memperoleh penimbang pada penelitian ini adalah metode Queen contiguity. Berdasarkan metode tersebut akan diperoleh jumlah ketetanggaan lokasi yang berdekatan dengan setiap kabupaten/kota. Sebagaimana tertera dalam tabel 1 .

Tabel 1.

Ketetanggaan Kabupaten/Kota Provinsi Kalimantan Selatan

\begin{tabular}{|c|c|c|}
\hline $\begin{array}{c}\text { Kode } \\
\text { Wilayah }\end{array}$ & Kabupaten & Kabupaten Tetangga \\
\hline 1 & Tanah Laut & Banjar, Tanah Bumbu, Banjarbaru \\
\hline 2 & Kotabaru & $\begin{array}{l}\text { Banjar, Hulu Sungai Selatan, Hulu Sungai } \\
\text { Tengah, Tanah Bumbu, Balangan } \\
\text { Tanah Laut, Kotabaru, Barito Kuala, Tapin, }\end{array}$ \\
\hline 3 & Banjar & $\begin{array}{l}\text { Hulu Sungai Selatan, Tanah Bumbu, } \\
\text { Banjarmasin, Banjarbaru }\end{array}$ \\
\hline 4 & Barito Kuala & Banjar, Tapin, Hulu Sungai Utara, Banjarmasin \\
\hline 5 & Tapin & $\begin{array}{l}\text { Banjar, Barito Kuala, Hulu Sungai Selatan, } \\
\text { Hulu Sungai Utara }\end{array}$ \\
\hline 6 & Hulu Sungai Selatan & $\begin{array}{l}\text { Banjar, Tapin, Kotabaru, Hulu Sungai Tengah, } \\
\text { Hulu Sungai Utara }\end{array}$ \\
\hline 7 & Hulu Sungai Tengah & $\begin{array}{l}\text { Kotabaru, Hulu Sungai Selatan, Hulu Sungai } \\
\text { Utara, Balangan }\end{array}$ \\
\hline
\end{tabular}




\begin{tabular}{cll}
\hline $\begin{array}{c}\text { Kode } \\
\text { Wilayah }\end{array}$ & \multicolumn{1}{c}{ Kabupaten } & \multicolumn{1}{c}{ Kabupaten Tetangga } \\
\hline 8 & Hulu Sungai Utara & $\begin{array}{l}\text { Barito Kuala, Tapin, Hulu Sungai Selatan, Hulu } \\
\text { Sungai Tengah, Tabalong, Balangan }\end{array}$ \\
9 & Tabalong & Hulu Sungai Utara, Balangan \\
10 & Tanah Bumbu & Kotabaru, Banjar, Tanah Laut \\
11 & Balangan & Kotabaru, Hulu Sungai Tengah, Hulu Sungai \\
12 & Banjarmasin & Utara, Tabalong \\
13 & Banjarbaru & Banjar, Barito Kuala \\
\hline
\end{tabular}

Sumber: data diolah

\section{Kondisi Pariwisata di Kalimantan Selatan}

Perekonomian Kalimantan Selatan yang masih didominasi oleh pertambangan batubara mulai diarahkan pada sektor ekonomi lain yang lebih berkesinambungan. Salah satu yang menjadi fokus pemerintah saat ini adalah sektor pariwisata. Dalam penelitian ini, pariwisata dibatasi pada beberapa kategori lapangan usaha yang berkaitan erat dengan sektor ekonomi tersebut, yaitu perdagangan, transportasi dan pergudangan, penyediaan akomodasi dan makan minum, dan jasa lainnya. Jika dilihat dalam PDRB Provinsi Kalimantan Selatan, setiap lapangan usaha pariwisata itu menyumbang sebesar 10,01 persen, 6,62 persen, 2,01 persen, dan 1,25 persen terhadap total perekonomian.
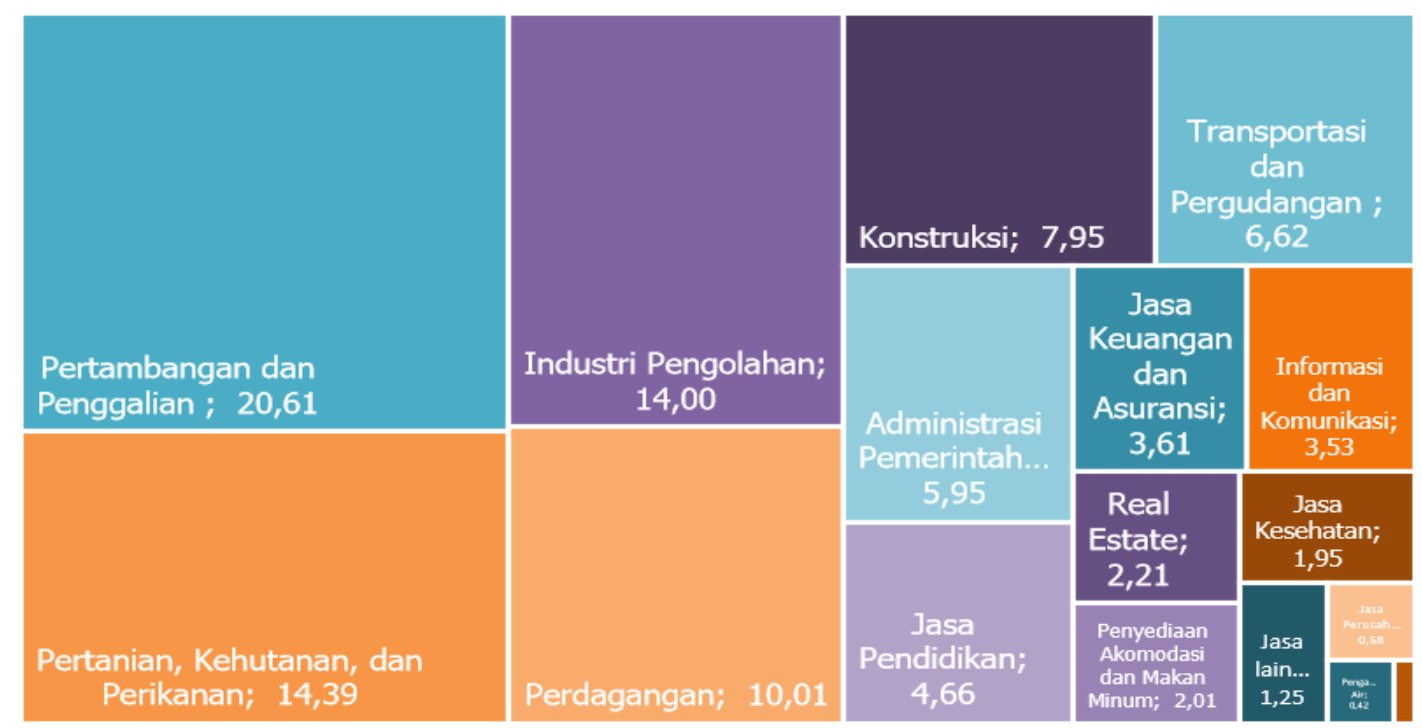

Gambar 5.

Distribusi PDRB Berlaku Provinsi Kalimantan Selatan Menurut Lapangan Usaha Tahun 2018 (Sumber: Badan Pusat Statistik Provinsi Kalimantan Selatan)

Jika dilihat persebaran tiap-tiap sektor pariwisata tersebut di dalam kabupaten/kota Provinsi Kalimantan Selatan, akan terlihat sebagai berikut. 


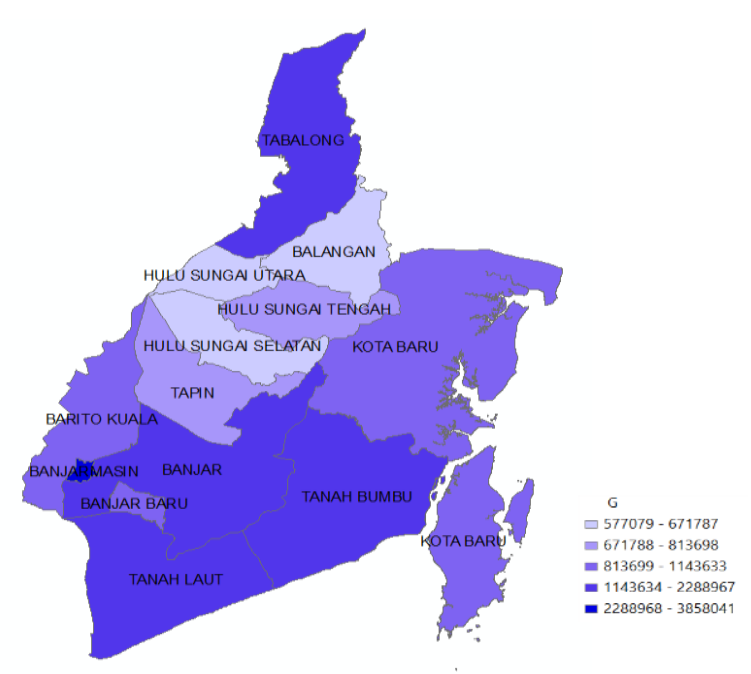

Gambar 6.

Peta Sebaran Lapangan Usaha Perdagangan Provinsi Kalimantan Selatan Tahun 2018 (Sumber: Badan Pusat Statistik Provinsi Kalimantan Selatan, diolah)

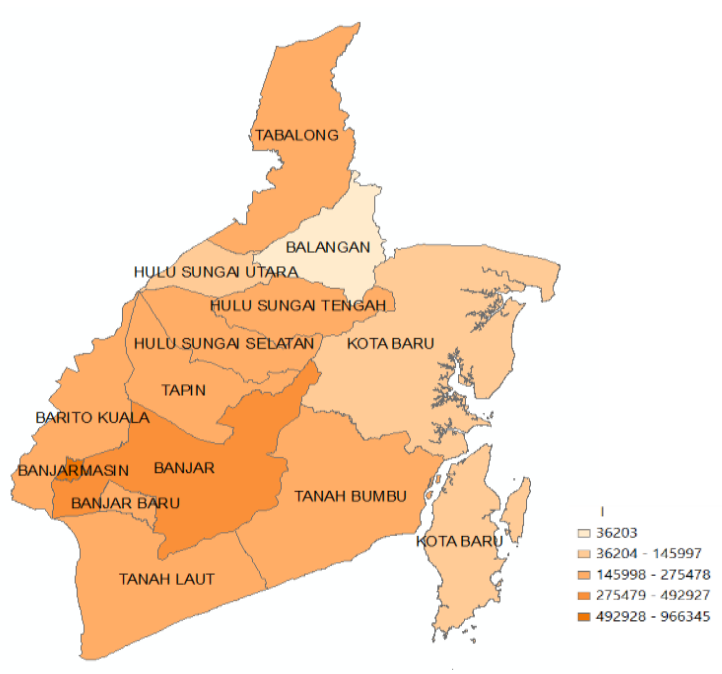

Gambar 8.

Peta Sebaran Lapangan Usaha Penyediaan Akomodasi dan Makan Minum Provinsi Kalimantan Selatan Tahun 2018 (Sumber: Badan Pusat Statistik Provinsi Kalimantan Selatan, diolah)

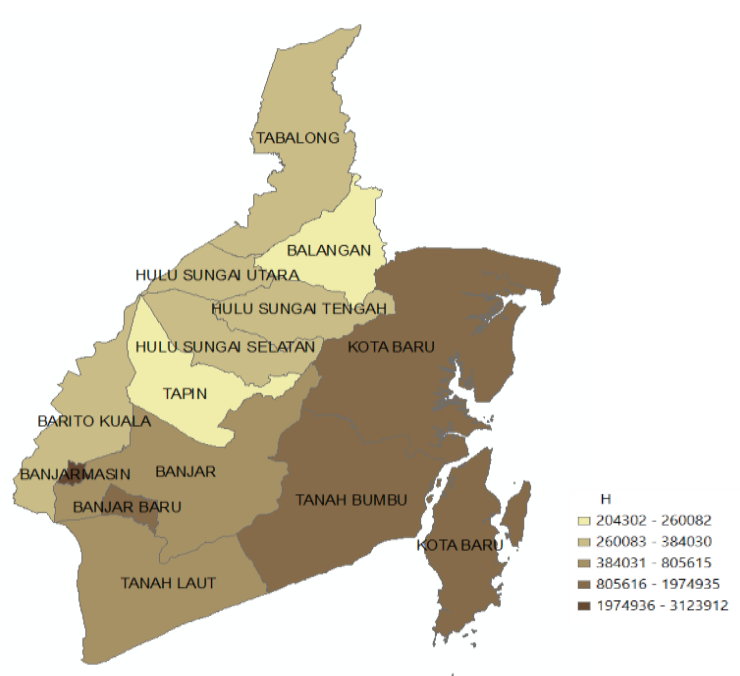

Gambar 7.

Peta Sebaran Lapangan Usaha Transportasi dan Pergudangan Provinsi Kalimantan Selatan Tahun 2018 (Sumber: Badan Pusat Statistik Provinsi Kalimantan Selatan, diolah)

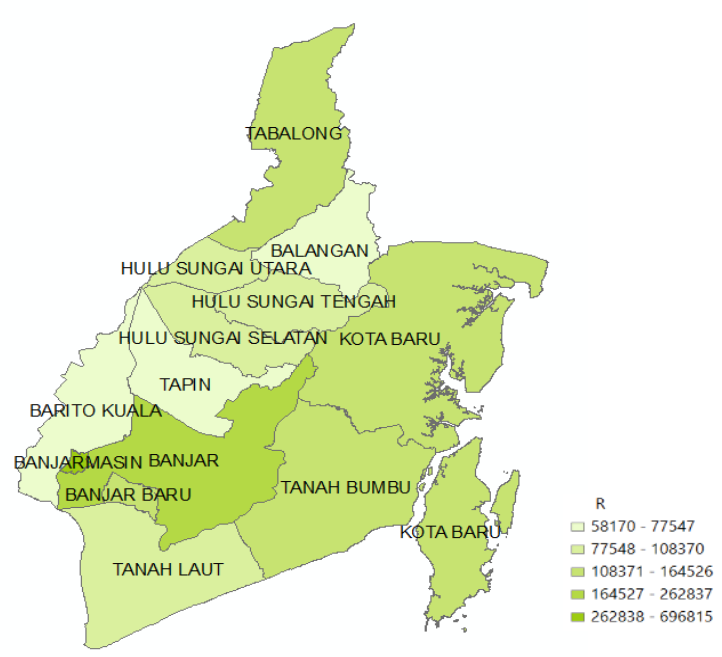

Gambar 9.

Peta Sebaran Lapangan Usaha Jasa Lainnya Provinsi Kalimantan Selatan Tahun 2018 (Sumber: Badan Pusat Statistik Provinsi Kalimantan Selatan, diolah) 
Secara keseluruhan sektor pariwisata pada gambar, terlihat bahwa terjadi pengelompokan dalam suatu wilayah. Pada lapangan usaha perdagangan, kontribusi nilai tambah perdagangan yang cukup besar mengelompok di wilayah Banjarmasin, Banjar, Tanah Laut, dan Tanah Bumbu. Untuk lapangan usaha penyediaan akomodasi dan makan minum, serta jasa lainnya, mengelompok di wilayah Banjarmasin dan Banjar. Sedangkan, untuk lapangan usaha transportasi dan pergudangan cukup menyebar di wilayah Banjarmasin, Banjarbaru, Tanah Bumbu, dan Kotabaru.

\section{Autokorelasi Spasial Sektor Pariwisata Perdagangan}

Untuk mengetahui ada tidaknya autokorelasi spasial antarlokasi pengamatan dapat dilihat menggunakan Indeks Moran. Pada lapangan usaha perdagangan, diperoleh Indeks Moran sebesar 0,168. Hal ini menunjukkan bahwa ada autokorelasi positif atau kabupaten/kota yang berdekatan memiliki pengaruh nilai tambah perdagangan yang positif antarkabupaten/kota satu dengan yang lainnya. Meskipun nilai Indeks Morannya tergolong kecil, dapat diketahui bahwa nilai tambah lapangan usaha perdagangan di Kalimantan Selatan memiliki pola spasial yang menggerombol.

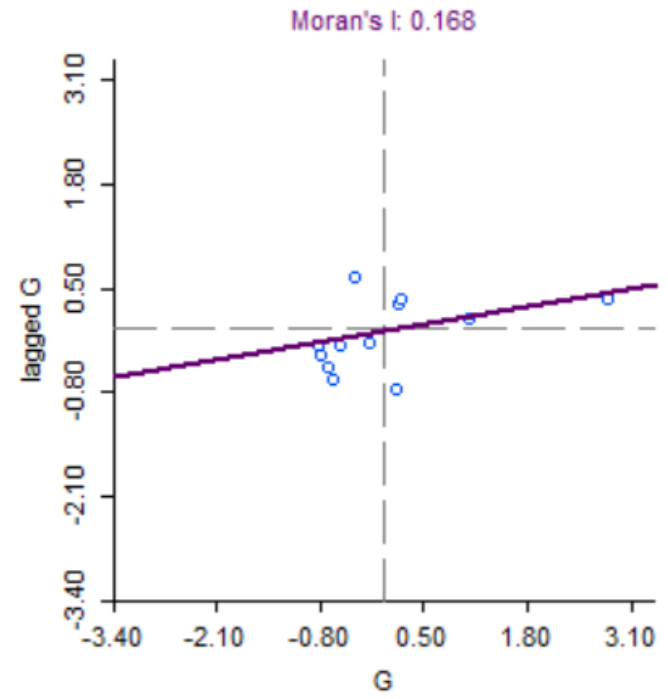

Gambar 10.

Indeks Moran Lapangan Usaha Perdagangan Tahun 2018 (Data diolah)

Moran scatterplot dapat dilihat pada Gambar 10. Gambar tersebut menunjukkan pola hubungan antara nilai tambah perdagangan antara satu wilayah dengan wilayah lainnya. Pada scatterplot tersebut dapat dilakukan pembagian wilayah berdasarkan kuadran. Kuadran I: Wilayah pada kuadran ini memiliki nilai tambah perdagangan yang tinggi dan berdekatan dengan wilayah lain yang memiliki nilai tambah perdagangan yang tinggi pula. Termasuk dalam kuadran ini adalah Tanah Laut, Banjar, Tanah Bumbu, dan Banjarmasin. Kuadran II: Wilayah pada kuadran ini memiliki nilai tambah perdagangan yang rendah dan berdekatan dengan wilayah lain yang memiliki nilai tambah perdagangan yang tinggi. Termasuk dalam kuadran ini adalah Barito Kuala dan Banjarbaru. Kuadran III: Wilayah pada kuadran ini memiliki nilai tambah perdagangan yang rendah dan berdekatan dengan wilayah lain yang memiliki nilai tambah perdagangan yang rendah pula. Termasuk dalam kuadran ini adalah 
Kotabaru, Tapin, Hulu Sungai Selatan, Hulu Sungai Tengah, Hulu Sungai Utara, dan Balangan. Kuadran IV: Wilayah pada kuadran ini memiliki nilai tambah perdagangan yang tinggi dan berdekatan dengan wilayah lain yang memiliki nilai tambah perdagangan yang rendah. Termasuk dalam kuadran ini adalah Tabalong.

Selanjutnya, untuk mengetahui wilayah yang memiliki autokorelasi spasial yang signifikan secara lokal dapat dilihat melalui Local Indicator of Spatial Autocorrelation (LISA). Pada LISA lapangan usaha perdagangan, diketahui bahwa kabupaten yang memiliki autokorelasi signifikan adalah Kabupaten Tanah Bumbu karena kabupaten tersebut memiliki nilai tambah perdagangan yang besar namun berdekatan dengan kabupaten/kota yang memiliki nilai tambah perdagangan yang rendah. Sedangkan, Kabupaten Hulu Sungai Utara dan Hulu Sungai Tengah memiliki autokorelasi yang signifikan dengan kabupaten/kota yang berdekatan dengan kabupaten tersebut karena nilai tambah perdagangan kedua kabupaten tersebut tergolong rendah dan berdekatan dengan kabupaten/kota yang juga memiliki nilai tambah perdagangan yang rendah.

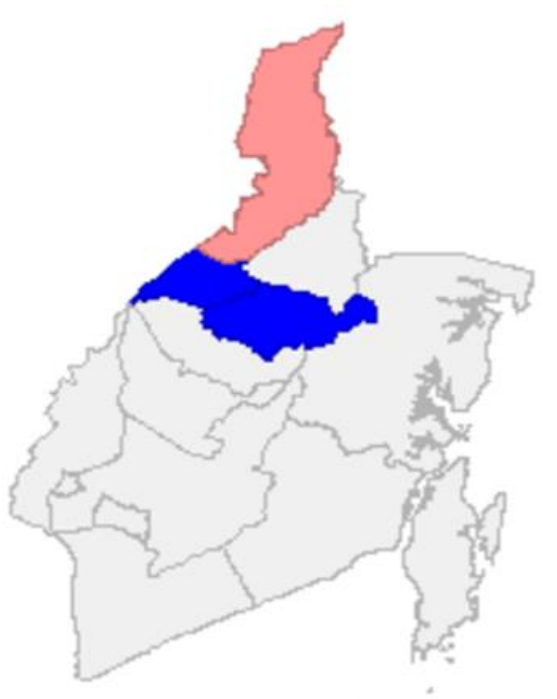

Gambar 11.

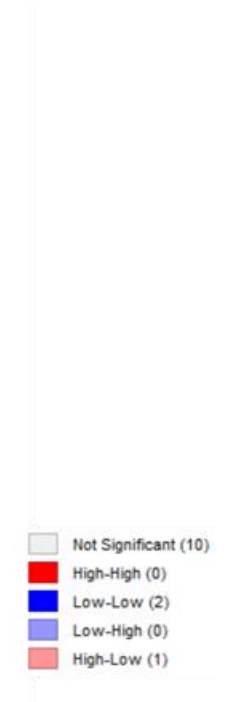

High-Low (1)

Pola Signifikansi Pengujian LISA Lapangan Usaha Perdagangan Provinsi Kalimantan Selatan Tahun 2018 (Data diolah)

\section{Transportasi dan Pergudangan}

Indeks Moran sektor pariwisata yang berfokus pada lapangan usaha transportasi dan pergudangan sebesar 0,017. Hal ini menunjukkan bahwa ada autokorelasi positif atau kabupaten/kota yang berdekatan memiliki pengaruh nilai tambah transportasi dan pergudangan yang positif antarkabupaten/kota satu dengan yang lainnya. Meskipun nilai Indeks Morannya tergolong kecil, dapat diketahui bahwa nilai tambah lapangan usaha transportasi dan pergudangan di Kalimantan Selatan memiliki pola spasial yang menggerombol. 


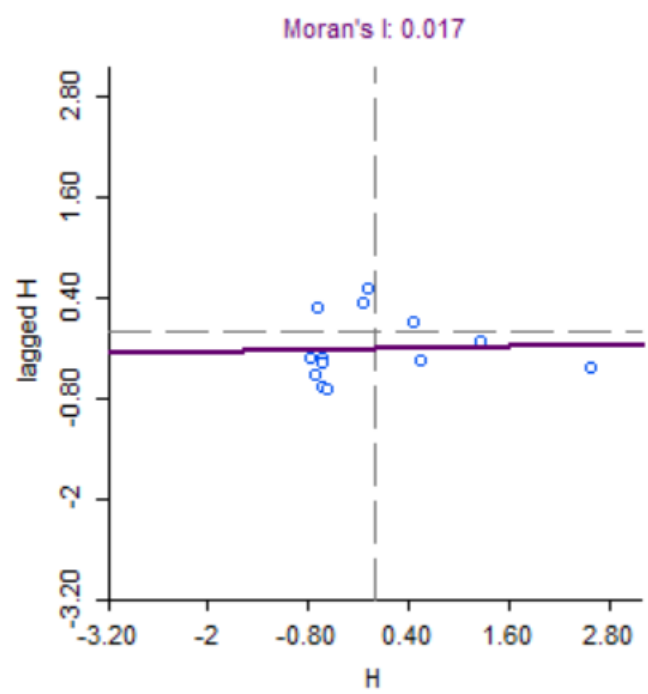

Gambar 12.

Indeks Moran Lapangan Usaha Transportasi dan Pergudangan Tahun 2018 (Data diolah)

Pola spasial lapangan usaha transportasi dan pergudangan yang dibagi ke dalam empat kuadran Indeks Moran adalah sebagai berikut.

Kuadran I: Wilayah pada kuadran ini memiliki nilai tambah transportasi dan pergudangan yang tinggi dan berdekatan dengan wilayah lain yang memiliki nilai tambah transportasi dan pergudangan yang tinggi pula. Termasuk dalam kuadran ini adalah Tanah Bumbu.

Kuadran II: Wilayah pada kuadran ini memiliki nilai tambah transportasi dan pergudangan yang rendah dan berdekatan dengan wilayah lain yang memiliki nilai tambah transportasi dan pergudangan yang tinggi. Termasuk dalam kuadran ini adalah Tanah Laut, Banjar, dan Barito Kuala.

Kuadran III: Wilayah pada kuadran ini memiliki nilai tambah transportasi dan pergudangan yang rendah dan berdekatan dengan wilayah lain yang memiliki nilai tambah transportasi dan pergudangan yang rendah pula. Termasuk dalam kuadran ini adalah Tapin, Hulu Sungai Selatan, Hulu Sungai Tengah, Hulu Sungai Utara, Tabalong, dan Balangan.

Kuadran IV: Wilayah pada kuadran ini memiliki nilai tambah transportasi dan pergudangan yang tinggi dan berdekatan dengan wilayah lain yang memiliki nilai tambah transportasi dan pergudangan yang rendah. Termasuk dalam kuadran ini adalah Kotabaru, Banjarmasin, dan Banjarbaru.

Sedangkan kabupaten/kota yang memiliki autokorelasi pola spasial yang signifikan pada lapangan usaha transportasi dan pergudangan, dapat dilihat melalui pengujian LISA. Kabupaten Hulu Sungai Utara memiliki autokorelasi yang signifikan dengan kabupaten/kota yang berdekatan dengan kabupaten tersebut karena nilai tambah transportasi dan pergudangan kabupaten tersebut tergolong rendah dan berdekatan dengan kabupaten/kota yang juga memiliki nilai tambah transportasi dan pergudangan yang rendah. Sedangkan, kabupaten/kota lain yang signifikan adalah Kabupaten Banjar karena nilai tambah transportasi dan pergudangan kabupaten tersebut tergolong rendah, tetapi berdekatan dengan kabupaten/kota yang memiliki nilai tambah transportasi dan pergudangan tinggi. 


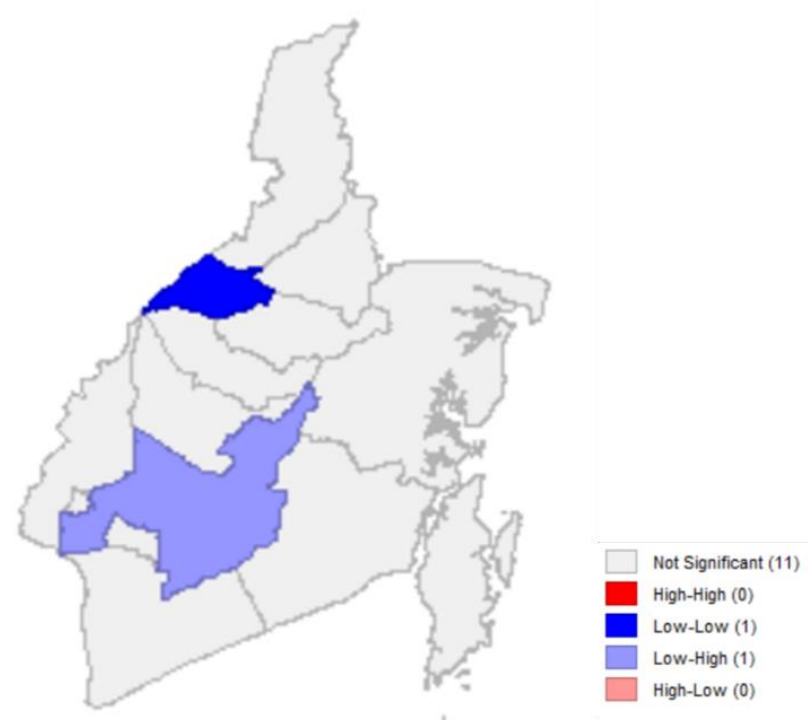

Gambar 13.

Pola Signifikansi Pengujian LISA Lapangan Usaha Transportasi dan Pergudangan Provinsi Kalimantan Selatan Tahun 2018 (Data diolah)

\section{Penyediaan Akomodasi dan Makan Minum}

Indeks Moran sektor pariwisata yang berfokus pada lapangan usaha penyediaan akomodasi dan makan minum sebesar 0,114. Hal ini menunjukkan bahwa ada autokorelasi positif atau kabupaten/kota yang berdekatan memiliki pengaruh nilai tambah penyediaan akomodasi dan makan minum yang positif antarkabupaten/kota satu dengan yang lainnya. Meskipun nilai Indeks Morannya tergolong kecil, tetapi dapat diketahui bahwa nilai tambah lapangan usaha penyediaan akomodasi dan makan minum di Kalimantan Selatan memiliki pola spasial yang menggerombol.

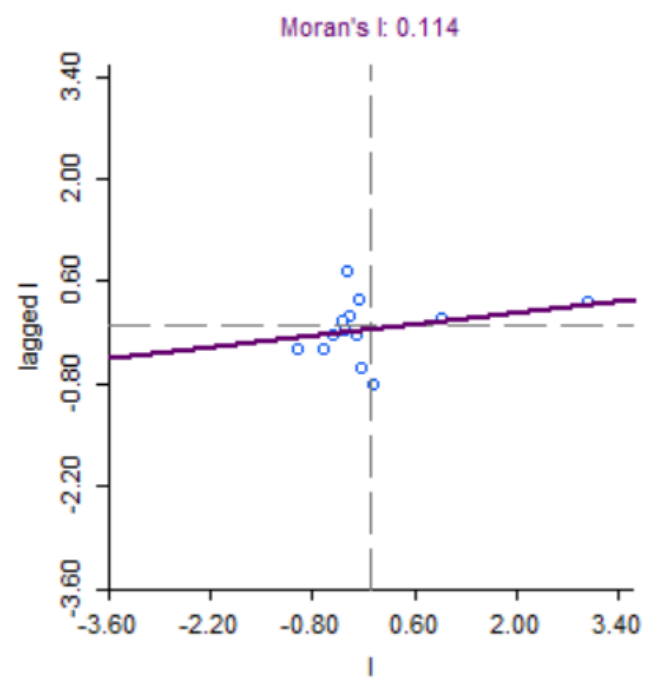

Gambar 14.

Indeks Moran Lapangan Usaha Penyediaan Akomodasi dan Makan Minum Tahun 2018

(Data diolah) 
Pola spasial lapangan usaha penyediaan akomodasi dan makan minum yang dibagi ke dalam empat kuadran Indeks Moran adalah sebagai berikut. Kuadran I: Wilayah pada kuadran ini memiliki nilai tambah penyediaan akomodasi dan makan minum yang tinggi dan berdekatan dengan wilayah lain yang memiliki nilai tambah penyediaan akomodasi dan makan minum yang tinggi pula. Termasuk dalam kuadran ini adalah Banjar dan Banjarbaru. Kuadran II: Wilayah pada kuadran ini memiliki nilai tambah penyediaan akomodasi dan makan minum yang rendah dan berdekatan dengan wilayah lain yang memiliki nilai tambah penyediaan akomodasi dan makan minum yang tinggi. Termasuk dalam kuadran ini adalah Tanah Laut, Barito Kuala, Tanah Bumbu, dan Banjarbaru. Kuadran III: Wilayah pada kuadran ini memiliki nilai tambah penyediaan akomodasi dan makan minum yang rendah dan berdekatan dengan wilayah lain yang memiliki nilai tambah penyediaan akomodasi dan makan minum yang rendah pula. Termasuk dalam kuadran ini adalah Kotabaru, Tapin, Hulu Sungai Selatan, Hulu Sungai Tengah, Hulu Sungai Utara, dan Balangan. Kuadran IV: Wilayah pada kuadran ini memiliki nilai tambah penyediaan akomodasi dan makan minum yang tinggi dan berdekatan dengan wilayah lain yang memiliki nilai tambah penyediaan akomodasi dan makan minum yang rendah. Termasuk dalam kuadran ini adalah Tabalong.

Kabupaten/kota yang memiliki autokorelasi pola spasial yang signifikan pada lapangan usaha penyediaan akomodasi dan makan minum melalui pengujian LISA dapat dilihat pada Gambar 15. Kabupaten Hulu Sungai Tengah memiliki autokorelasi yang signifikan dengan kabupaten/kota yang berdekatan dengan kabupaten tersebut karena nilai tambah penyediaan akomodasi dan makan minum kabupaten tersebut tergolong rendah dan berdekatan dengan kabupaten/kota yang juga memiliki nilai tambah penyediaan akomodasi dan makan minum yang rendah. Sedangkan kabupaten/kota lain yang signifikan adalah Kabupaten Tabalong karena nilai tambah penyediaan akomodasi dan makan minum kabupaten tersebut tergolong tinggi namun berdekatan dengan kabupaten/kota yang memiliki nilai tambah penyediaan akomodasi dan makan minum rendah.

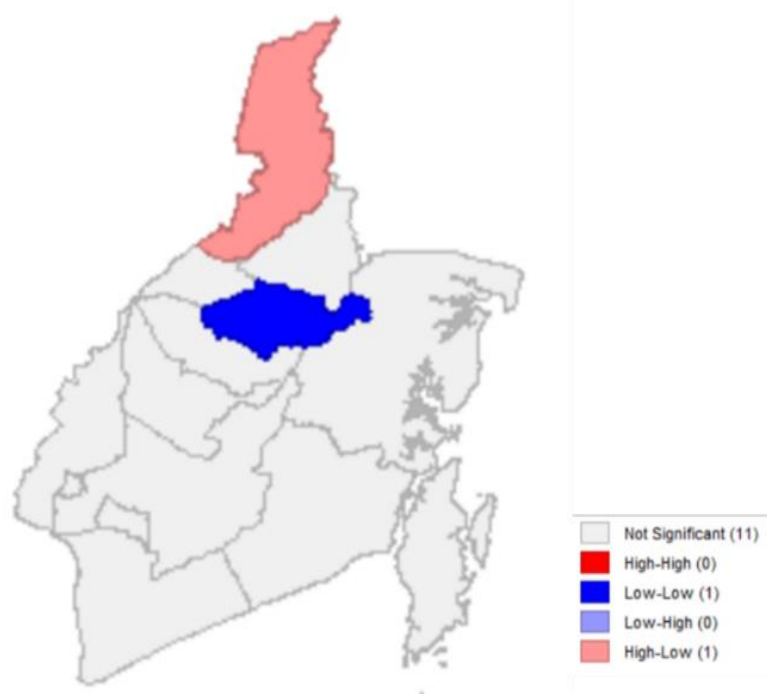

Gambar 15.

Pola Signifikansi Pengujian LISA Lapangan Usaha Penyediaan Akomodasi dan Makan Minum Provinsi Kalimantan Selatan Tahun 2018 (Data diolah) 


\section{Jasa Lainnya}

Indeks Moran sektor pariwisata yang berfokus pada lapangan usaha jasa lainnya sebesar 0,033. Hal ini menunjukkan bahwa ada autokorelasi positif atau kabupaten/kota yang berdekatan memiliki pengaruh nilai tambah jasa lainnya yang positif antarkabupaten/kota satu dengan yang lainnya. Meskipun nilai Indeks Morannya tergolong kecil, tetapi dapat diketahui bahwa nilai tambah lapangan usaha jasa lainnya di Kalimantan Selatan memiliki pola spasial yang menggerombol.

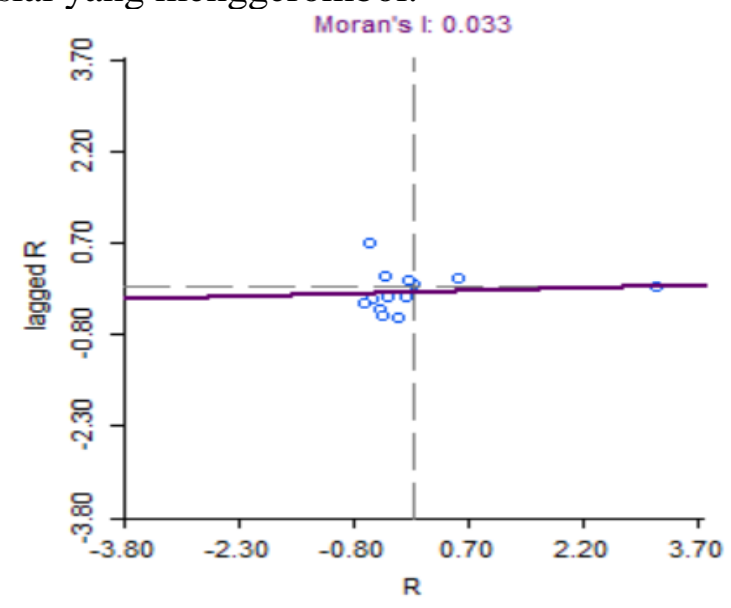

Gambar 16.

Indeks Moran Lapangan Usaha Jasa lainnya Tahun 2018 (Data diolah)

Pola spasial lapangan usaha jasa lainnya yang dibagi ke dalam empat kuadran Indeks Moran adalah sebagai berikut. Kuadran I: Wilayah pada kuadran ini memiliki nilai tambah jasa lainnya yang tinggi dan berdekatan dengan wilayah lain yang memiliki nilai tambah jasa lainnya yang tinggi pula. Termasuk dalam kuadran ini adalah Banjar, Tanah Bumbu, dan Banjarmasin. Kuadran II: Wilayah pada kuadran ini memiliki nilai tambah jasa lainnya yang rendah dan berdekatan dengan wilayah lain yang memiliki nilai tambah jasa lainnya yang tinggi. Termasuk dalam kuadran ini adalah Tanah Laut, Barito Kuala, dan Banjarbaru. Kuadran III: Wilayah pada kuadran ini memiliki nilai tambah jasa lainnya yang rendah dan berdekatan dengan wilayah lain yang memiliki nilai tambah jasa lainnya yang rendah pula. Termasuk dalam kuadran ini adalah Kotabaru, Tapin, Hulu Sungai Selatan, Hulu Sungai Tengah, Hulu Sungai Utara, Tabalong, dan Balangan. Kuadran IV: Wilayah pada kuadran ini memiliki nilai tambah jasa lainnya yang tinggi dan berdekatan dengan wilayah lain yang memiliki nilai tambah jasa lainnya yang rendah. Tidak ada kabupaten/kota yang termasuk dalam kuadran ini.

Kabupaten/kota yang memiliki autokorelasi pola spasial yang signifikan pada lapangan usaha jasa lainnya melalui pengujian LISA dapat dilihat pada Gambar 17. Hanya ada satu kabupaten yang termasuk memiliki autokorelasi pola spasial yang signfikan, yaitu Kabupaten Hulu Sungai Utara, karena nilai tambah jasa lainnya kabupaten tersebut tergolong rendah dan berdekatan dengan kabupaten/kota yang juga memiliki nilai tambah jasa lainnya yang rendah. 


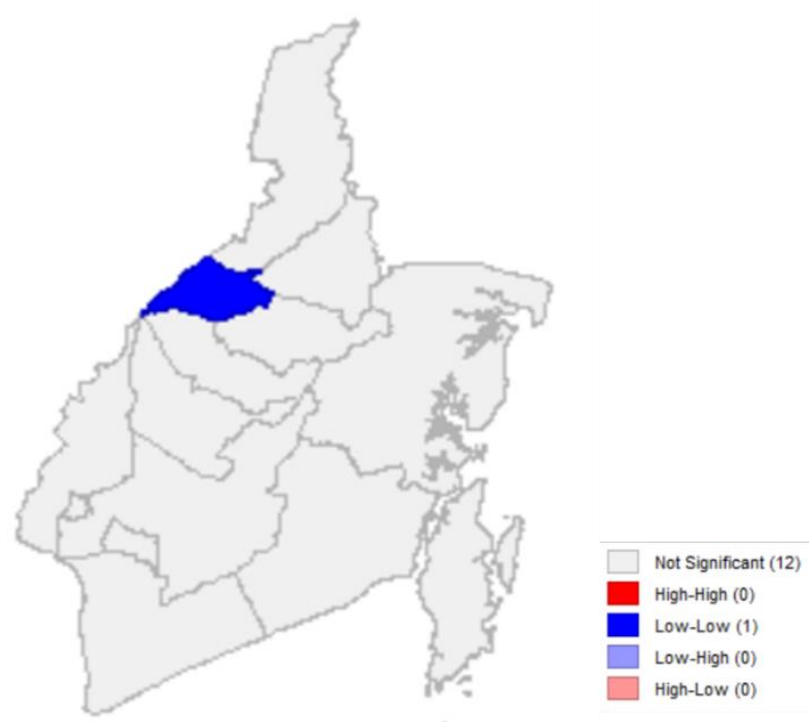

Gambar 17.

Pola Signifikansi Pengujian LISA Lapangan Usaha Jasa lainnya Provinsi Kalimantan Selatan Tahun 2018 (Data diolah)

\section{E. PENUTUP}

Dari penelitian yang berfokus pada sektor pariwisata ini dapat disimpulkan bahwa terdapat autokorelasi spasial yang positif pada tiap-tiap lapangan usaha. Hal ini terlihat dari Indeks Moran lapangan usaha perdagangan, transportasi dan pergudangan, penyediaan akomodasi dan makan minum, dan jasa lainnya masing-masing sebesar 0,$168 ; 0,017 ; 0,114$; dan 0,033. Berdasarkan Indeks Moran tersebut, diketahui bahwa dari beberapa lapangan usaha yang termasuk sebagai sektor pariwisata, lapangan usaha perdagangan memiliki autokorelasi spasial yang terbesar dibanding lapangan usaha lainnya.

Autokorelasi di sektor pariwisata tersebut berkontribusi pada perkembangan administrasi negara, khususnya terkait kebijakan yang terintegrasi antarkota/kabupaten. Pemerintah daerah khususnya, dapat berfokus pada lapangan usaha perdagangan untuk menjadikan lapangan usaha tersebut sebagai sektor pariwisata yang tidak hanya berdampak pada peningkatan satu kabupaten/kota, tetapi juga menyebar pada wilayah lainnya. Penyebaran dampak ini diharapkan dapat mengurangi kesenjangan ekonomi yang terjadi antarwilayah di Provinsi Kalimantan Selatan.

Penelitian ini masih perlu dikembangkan dengan melakukan analisis mendalam untuk melihat faktor yang memengaruhi keterkaitan spasial sektor pariwisata antarkabupaten/kota. Selain itu, perlu dilakukan kajian lebih lanjut mengenai variabel yang digunakan untuk mengukur pariwisata, misalnya menggunakan indeks komposit sektor pariwisata. Kajian terkait lapangan usaha yang menggambarkan sektor pariwisata pun perlu digali lebih dalam dengan mengetahui besaran nilai pariwisata di dalam masing-masing lapangan usaha di PDRB.

\section{DAFTAR PUSTAKA}

Adeola, Ogechi. Olaniyi Evans, \& R. E. H. (2018). Tourism And Economic Wellbeing in Africa (Issue 93685). Positive Tourism in Africa. Hal: 147-160.

Aleksandar, Lugonja. Knezevic Marija., \& G. R. (2017). The Role of Spatial Planning for Sustainable Tourism Development in Bosnia and Herzegovina. Poslovnu Studiji 
Business Studies, 9(17-18), 271-284.

Anselin, L. (1988). Spatial Econometrics: Methods and Models. Academic Publishers. Hal: 39-80.

Atan, S., \& Arslanturk, Y. (2012). Tourism and Economic Growth Nexus: An Input Output Analysis in Turkey. Procedia - Social and Behavioral Sciences, 62(1936), 952-956.

Badan Pusat Statistik Provinsi Kalimantan Selatan. (2019). Provinsi Kalimantan Selatan Dalam Angka 2019. Banjarbaru. Badan Pusat Statistik. Hal: 1-570.

Budirahmayani, A. \& K. (2019). Tourism and Economic Growth: Spatial Perspective. Atlantis Press. Advances in Social Science, Education and Humanities Research (ASSEHR), 216, 7-24.

Constantin, D. L. \& A. R. (2018). A Spatial Analysis of Tourism Infrastructure in Romania: Spotlight on Accommodation and Food Service Companies. Region, 5(1), 1-16.

Dubé, J. and D. L. (2014). Spatial Econometrics Using Microdata. ISTE Ltd and John Wiley \& Sons, Inc, pg:60.

Frechtling, D. C. (2008). Measurement and Analysis of Tourism Economic Contributions for Sub-National Regions Through The Tourism Satellite Account. The International Tourism Knowledge as Value Advantage of Tourist Destinations, 1-20.

Fu, W. J., Jiang, P. K., Zhou, G. M., \& Zhao, K. L. (2014). Using Moran's i and GIS to Study The Spatial Pattern of Forest Litter Carbon Density in a Subtropical Region of Southeastern China. Biogeosciences, 11(8), 2401-2409.

Kementerian PPN/Bappenas. (2019). Rencana Pembangunan Jangka Menengah Nasional 2020-2024. Jakarta. Kementerian PPN/Bappenas. Hal: 1-313.

Lutfi, A., Aidid, M. K., \& Sudarmin. (2019). Identifikasi Autokorelasi Spasial Angka Partisipasi Sekolah di Provinsi Sulawesi Selatan Menggunakan Indeks Moran. 1(2), 1 $\underline{8 .}$

McKelly, D. H., Rogerson, C. M., Van Huysteen, E., Maritz, J., \& Ngidi, M. (2017). Spatial Trends in Tourism Within South Africa: The Expected And The Surprising. South African Journal of Geomatics, 6(2), 219.

Melecky, L. (2015). Spatial Autocorrelation Method for Local Analysis of The EU. Procedia Economics and Finance, 23, 1102-1109.

Nisa, E. K. (2017). Identifikasi Spatial Pattern dan Spatial Autocorrelation Pada Indeks Pembangunan Manusia Provinsi Papua Barat Tahun 2012. Jurnal At-Taqaddum, 9(2), 202-226.

Rahmawati, R., Safitri, D., \& Fairuzdhiya, O. U. (2015). Analisis Spasial Pengaruh Tingkat Pengangguran Terhadap Kemiskinan di Indonesia. Media Statistika, 8(1), 23-30.

Romão, J., \& Saito, H. (2017). A Spatial Analysis On The Determinants of Tourism Performance in Japanese Prefectures. Asia-Pacific Journal of Regional Science, 1(1), 243-264.

Rukini. (2017). Pola Keterkaitan Spasial Berdasarkan Produksi Pajale (Padi Jagung Kedelai) Di Kabupaten Grobogan Tahun 2015. April 2015, 223-231.

Salima, Bouayad Agha, \& M.-P. de B. (2018). Handbook of Spatial Analysis. Insee Eurostat. Hal: 51-68.

Stankov, U. et al. (2017). Tourism and Regional Development: A Spatial Econometric Model for Portugal at Municipal Level. Serbia. Geographica Pannonica, 21(2), 106114.

The World Bank Group. (2017). 20 Reasons Sustainable Tourism Counts for Development Knowledge (pp. 1-28). The World Bank Group. www.worldbank.org.

United Nations. (2010). International Recommendations for Tourism Statistics 2008. In 
International Recommendations for Tourism Statistics 2008. United Nations. Hal: 1277.

Williams, G. (2016). Economic Impacts From Development of The Coastal Town In

Queensland on Tourism and Regional Economy. Resources, 5(4), 1-16.

Wuryandari, T., Hoyyi, A., Kusumawardani, D. S., \& Rahmawati, D. (2014). Identifikasi Autokorelasi Spasial Pada Jumlah Pengangguran di Jawa Tengah Menggunakan Indeks Moran. Media Statistika, 7(1), 1-10.

Zhongmei, G. \& W. J. (2012). Study on the Tourism Development in Transformation of Resource Based Cities -Take Jiaozuo City as an Example. International Proceedings of Economics Development and Research, 49(28), 145-149. 